\title{
Multimodal analysis of metaphors in political-religious discourse: a cognitive-semiotic approach
}

\author{
Maíra Avelar* \\ Paulo Henrique Aguiar Mendes**
}

\begin{abstract}
This paper analyzes the interrelation between gestures and speech in the construction of multimodal metaphors in the "legislative session" genre. Based on Multimodal Semiotic Blending (MSB), an adaptation of Brandt and Brandt's (2005) model (MIRANDA; MENDES, 2014; AVELAR, in press), an illustrative analysis of the multimodal metaphors found in the sessions was performed, focusing on the verbal and gestural resources used by the participants. To do so, five scenes were selected from two legislative sessions performed by two so-called "Representative-pastors" of the Brazilian House of Representatives: Marco Feliciano and Silas Malafaia. Finally, the metaphors and the gestures performed by both politicians were compared. The conclusion reached in this study demonstrated how MSB can be relevant when analyzing the iconicity of material resources (mainly gestures) used by the participants.
\end{abstract}

Keywords: Cognitive Semiotics. Multimodal Semiotic Blending. Politicalreligious discourse. Brazilian politics. Legislative sessions.

\section{INTRODUCTION}

Taking into consideration that there is a lack of studies on multimodality applied to the political domain, this study analyzes the metaphors that gradually emerged in the legislative sessions performed by two so-called "Representative-pastors", who are evangelical Congressmen from the Brazilian House of Representatives, taking into consideration two factors: the vocal, belonging to the auditory modality, and the gestural, belonging to the visual modality. To analyze the selected scenes from the debates (further addressed in Section 3), an adapted version from Brandt and

* Professora Adjunta da Universidade Estadual do Sudoeste da Bahia - UESB, docente do Programa de Pós-graduação em Linguística (PPGLin).

** Professor Adjunto da Universidade Federal de Ouro Preto - UFOP. 
Brandt's Cognitive Semiotic Model (2005) (addressed in detail in Subsection 1.1) was chosen, as it proved to be a model that encompasses the enunciative scenario, allowing for a dynamic analysis of the metaphors used by the Representatives and, more importantly, allowing for a detailed and integrated analysis of the verbal and gestural content together with the linguistic content.

Based on Turner's (2007) assumptions, the main hypothesis that guides this research is that the more entrenched the metaphoric expression is in our conceptual system, the harder it is to recognize such an expression as metaphoric. By contrast, the less entrenched the expression is in our conceptual system, the easier it is to recognize it as a metaphoric expression. When approaching the difference between literal and metaphoric meaning, Turner states that this label "does not refer to cognitive operations [that are] fundamentally different" (TURNER, 2007, p. 1). According to the author, the degree of judgment of an expression as literal or metaphoric is intimately related to the degree of productive entrenchment or, in Müller and Cienki's (2009) words, to the degree of conventionality - of a conceptual connection. Thus, the higher the degree of productive entrenchment, or conventionality, the lower the chance of an expression being judged as metaphoric or the faster the metaphor processing. This will be further discussed in Subsection 1.2 .

Subsequently, the methods for collecting, selecting, and coding the corpus are presented in the second section. In the third section, five samples, three from Malafaia's legislative session and two from Feliciano's, are analyzed. In each of these, the gestures are photographed, described, and analyzed, followed by the application of Multimodal Semiotic Blending (MSB). In Section 4, the results are gathered and discussed, and in the final section, the validation of the initial hypothesis and the relevance of MSB for Cognitive Semiotics is discussed.

\section{THEORETICAL BACKGROUND}

In this section, we present the background theories regarding metaphoric analysis: we present our adapted version (MIRANDA; MENDES, 2014) of Brandt's Cognitive Semiotic Model (2005), called the Multimodal Semiotic Blending (MSB) model, also presenting a more detailed discussion about gesture analyses, formulating categories such as multimodal metaphoricity in speech and gesture compounds (MÜLLER; CIENKI, 2009), as well as gesture excursion (KENDON, 2004). 


\subsection{Brandt and Brandt's Cognitive Semiotic Model and Multimodal Semiotic Blending}

The model proposed by Brandt and Brandt (2005) makes it possible to analyze how the subjects, in situated interactions, cognitively process blendings by projecting an architecture of spaces (cognitive frames) that has a semiotic basis. According to the authors, there is a semiotic base space that can be understood as the participant's shared representation of the situation of communication, which is basic for meaning construction in a determined semantic network. Some modifications have been made to the architecture of the spaces originally presented by Brandt and Brandt (2005), mainly in the Semiotic Space, which was transformed into a Grounded space, as defined by Oakley (2009). Finally, to better suit our analysis of multimodal data, we (MIRANDA; MENDES, 2014; AVELAR, in press) have proposed that the Presentation space (which corresponds to the sign in Peircean terms) should be unfolded into a Signifier (gestural and prosodic resources) and a Signified (linguistic resources).

In the final modified version, the architecture of the spaces consists of the: (i) grounded semiotic space (which unfolds into three spheres: semiosis, strictly speaking, as an instance of language acts performed by the interlocutors; the communication situation, in which the participants of the interaction are found; and the wider phenomenological world, accessible to our experience); (ii) input spaces, called presentation spaces (textual instance), which unfold into two dimensions: signifier (gestural and prosodic resources) and signified (linguistic resources), and reference space (object instance); (iii) virtual space (blending), projected from the scenario element (frame) selection of the last two spaces; and (iv) relevance space, which guides the emerging meaning of the virtual space. This architecture of spaces, known as MSB, can be seen below: 


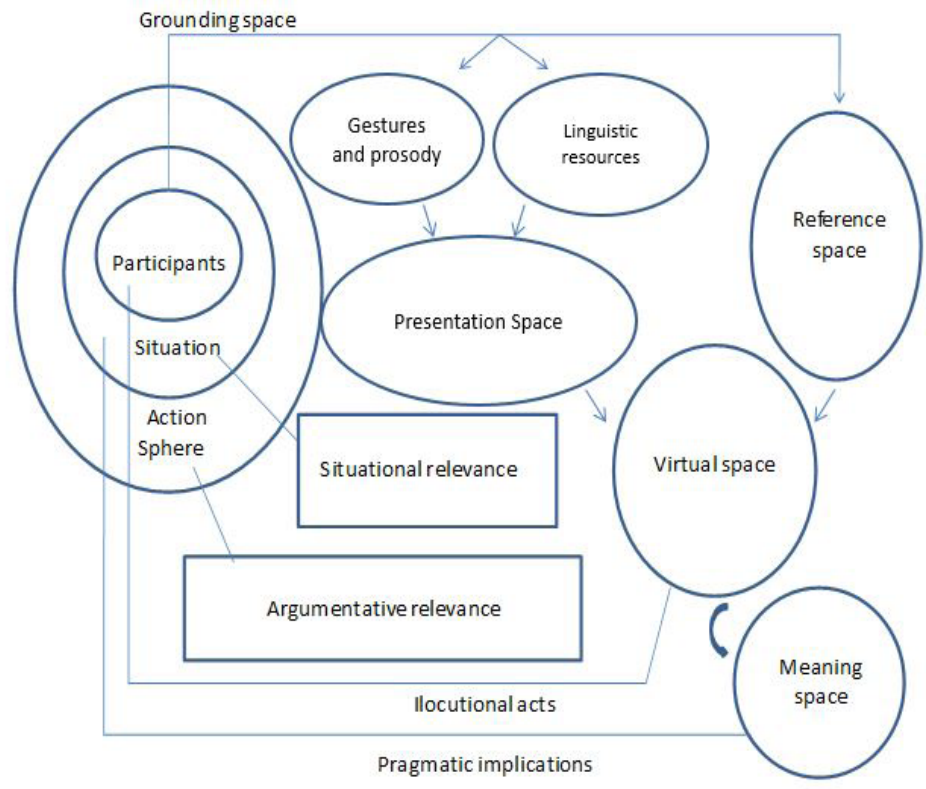

FIGURE 3 - Multimodal Semiotic Blending (MSB model)

Source: MIRANDA; MENDES, 2014.

As can be noted in both the description and the diagram, in MSB (MIRANDA; MENDES, 2014; AVELAR, in press), the presentation space, originally presented as a single space in the original model (BRANDT; BRANDT, 2005), first unfolds into two: one related to the "here-and-now" of the enunciation and its materialistic properties, and the other related to the linguistic resources, that is, its lexical properties and syntagmatic relations, used by the participants to build the utterance. Consequently, the presentation space results in the merger of what is said and how it is said by the participants of the enunciative scene. The highlight of the prosodic and gestural features is a relevant tool to analyze the specificities of these body resources and their relation to the linguistic content, which can be seen in some applications of the model in Section 4. 


\subsection{Metaphoricity and multimodality}

Rather than speaking of Conceptual Metaphor in terms of a static cognitive principle, the concept of metaphoricity is a quite useful approach to the emergence of metaphor in interactions, since metaphorical elaborations can be triggered in several modalities and successively over time. Therefore, metaphoricity is approached as a general cognitive principle, in which metaphoric mappings are processed online. The analysis of syntactic, semantic, prosodic, and gestural contexts reveals that it is a dynamic property of linguistic items, which can be found in the foreground, thus receiving focused attention. To analyze the gradual emergence of metaphors in the debate, we selected specific categories related to multimodality, which will be further developed in the following subsections, mainly addressing gesture analysis, since it is quite uncommon to analyze these within a political-religious context.

\subsubsection{Gesture excursion}

According to Kendon (2004), a gesture performance includes three phases in which a movement excursion is made, also called a Gestural Unit (GU) or an “excursion succession” (KENDON, 2004, p. 110):

(a) Preparation: optional phase, in which the limbs move from a relaxed or resting position;

(b) Stroke: mandatory phase, in which the gestural expression is performed, showing clear dynamic movements that require the focus of both effort and energy. In this phase, considered the gesture's peak, hands tend to describe forms and complete movement patterns, or a brief stop in the movement, in which the limbs are kept still before relaxing and returning to the initial position. This second possibility was called the post-stroke hold (KITA apud KENDON, 2004, p. 112). The combination of stroke and post-stroke can be considered a "gestural phrase" (KENDON, 2004), as these are phrases that convey meaning or gestural expression;

(c) Retraction: optional phase, in which there is a movement retraction toward the initial relaxed or resting position.

The GU can be defined as the complete excursion of the movements, which starts (preparation) and ends (retraction) with the relaxing of the limbs and reaches 
its peak in the stroke. It is important to note that the GU can include one or more Gesture Phrases (GP): these are identified when there is a gestural stroke action sequence. Thus, the GP encompasses the preparation phase and the stroke phase, as well as the hold phases (pre and post-stroke) between the stroke sequences and the retraction. These descriptions will be clarified by the examples given in the Analysis section (Section 3).

\subsubsection{Multimodal metaphoricity in verbal-gestural compounds}

In the context of multimodal metaphoricity, it is possible to describe two patterns of the relation between gestures and speech (MÜLLER; CIENKI, 2009, p. 307):

(1) It is possible to find the same source and the same target in different modalities. In these cases, the gesture embodies the source-domain of the verbal metaphoric expression, indicating that the metaphoricity of that expression was activated or was in the foreground of the speaker's attention.

(2) It is also possible to find different sources and the same target in different modalities. In these cases, we find a gestural metaphoric expression, together with a target that is verbalized in a non-metaphoric manner.

These two different possibilities will be discussed in detail in the Analysis section (Section 3).

\section{MATERIAL AND METHODS}

Our corpus consists of five scenes, from the two analyzed videos, collected from TV Câmara's (House of Representatives TV) Youtube channel. Both Representative-pastors are from the Partido Social Cristão (Social-Christian Party), a right-wing party consisting, in its majority, of evangelical politicians. Silas Malafaia's video corresponds to a "Solemn Session in Honor of the Family Day". In his speech, which lasts $11 \mathrm{~min} 42 \mathrm{sec}$, the pastor supports the concept of a "nuclear family", which is, according to him, "the father, the mother and the offspring" and "the support for the human race." In Feliciano's video, a plenary session that lasts $4 \mathrm{~min} 02 \mathrm{sec}$, he also supports the traditional family, taking a position against the gay kiss, which aired in a prime-time soap opera, and stating 
that "we are a conservative country, and we love the family."

To describe the five sequences, according to Kendon's (2004) description of the gesture excursion (see Subsection 2.1.2), all gestural strokes presented in each gesture excursion that contained a verbal-gestural metaphor were photographed. In addition, we have highlighted in bold the verbal content that co-occurs with the gestural stroke. We used captions, both to show this correlation between the gestural stroke and the verbal content, and to provide the description of the movement made by the hands and the forearms.

\section{DATA ANALYSIS}

\subsection{Silas Malafaia's speech}

To analyze the multimodal metaphors in Malafaia's speech, we have selected three scenes: the first one from the initial part of the video $(3 \mathrm{~min} 07 \mathrm{sec})$, the second from the middle portion ( $7 \mathrm{~min} 15 \mathrm{sec}$ ), and the last from the end (11 $\mathrm{min}$ $07 \mathrm{sec})$.

\section{Sequence \#1}

"O que nós chamamos de família nuclear $(1,2)$ é um homem (3), uma mulher (4) e sua prole (5)"/ "What we call nuclear family $(1,2)$ is a man (3), a woman (4), and their offspring"(5).

(1)

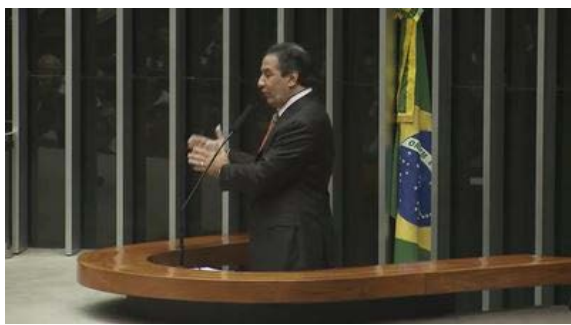

(2)

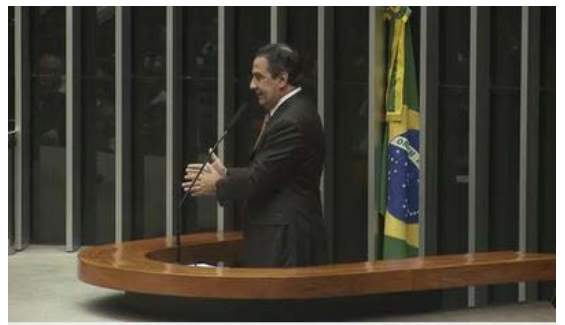

Source: TV Câmara's (House of Representatives TV) Youtube channel.

Parallel hands, palms facing each other, fingers extended, forearms in descending movement 
(3)

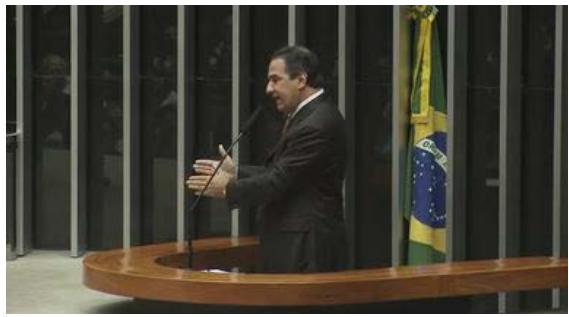

(4)

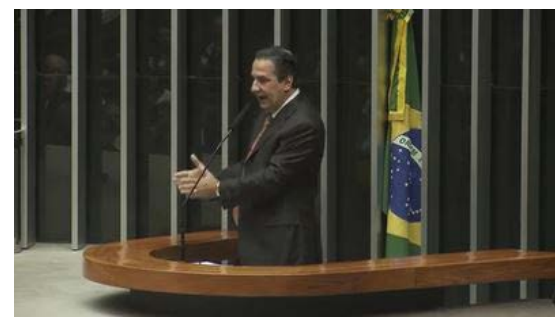

(5)

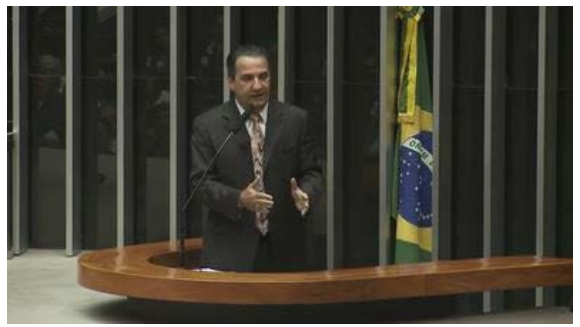

Source: TV Câmara's (House of Representatives TV) Youtube channel.

Parallel hands, palms facing each other, fingers extended, forearms in descending movement. Hands and forearms on the left (3), in the center (2) and on the right (5) of the body.

In this first sequence, Malafaia presents a typically traditional and conservative definition of family, based on what he calls "heteronormative relations". To do so, he approaches the concept of a "nuclear family", referred as "the main cell of society". This idea of a "nuclear family", theoretically formulated in the twentieth century by Social Psychology, presents a highly conventionalized degree of metaphoricity, anchored in the polysemy of "nuclear", referring to the central part/element in the composition of any structure. This metaphoric interpretation is strengthened by the "the main cell of society" definition, which structures the target-domain "family/society" in terms of the source-domain "cell/organism." Considering the sequence of gestures that co-occur with the pastor's speech, the speaker spatially demarcates, from right to left, the place for each one of the constitutive elements of the traditional family: "a man", "a woman" and "their offspring." 


\section{Sequence \#2}

"O ser humano é como uma esponja (1a, 1b)"./ "The human being is like a sponge $(1,2)$ ".

(1)

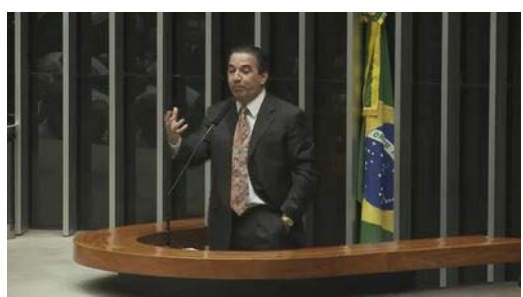

(2)

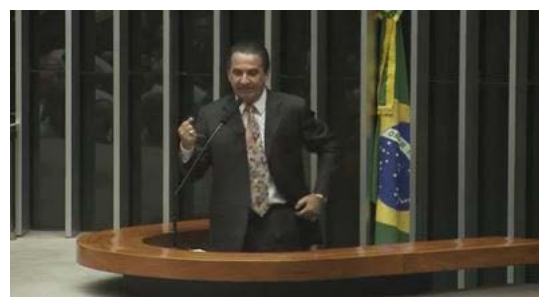

Source: TV Câmara's (House of Representatives TV) Youtube channel.

(1) Palm-oblique open right hand, oblique forearm, and partially bent fingers

(2) Fist-closed right hand, vertical forearm moving towards the body.

The second scene presents a less entrenched/conventionalized degree of metaphoricity. The selected utterance is also a definition, but it is rhetorically formulated as an analogy. When Malafaia says that "the human being is a sponge", it can produce different interpretations, as the lexical item "sponge" activates a specific conceptual and experiential domain that needs to be processed from projections that can be relevant to the "human being's" conceptual and experiential domain.

The contextual and co-textual factors are very important to this sample's metaphoric interpretation. The speaker's identity as a member of the Parliament and as a pastor who makes a speech in the House of Representatives in a solemn session in honor of the family is relevant in selecting the possible meaning effects - this will be discussed in the next section (Section 4). Furthermore, the analyzed utterance co-text is also important to the activation of relevant metaphoric projections: "Fellows, [there are] three things the parents leave to their children, take note: example, example, and example" is the precedent utterance, and "The child acknowledges the authority and claims for the authority" is the subsequent utterance. But it is the enactment gesture of squeezing a sponge, opening and closing the hand towards the body, that is responsible for the metaphoricity processing in this sequence. This gesture is crucial to the projection of properties 
such as porosity and absorption capacity. These are elements from the "sponge" source-domain, projected in the "human being" target-domain, as being able to absorb examples and authority from the family. This interpretation is coherent with the speaker's political and moral standpoint.

\section{Sequence \#3}

"Aqui está a sustentação (1a, 1b, 1c) da história da raça humana"/ "Here is the support $(1 \mathrm{a}, 1 \mathrm{~b}, 1 \mathrm{c})$ for the history of the human race".

(1)

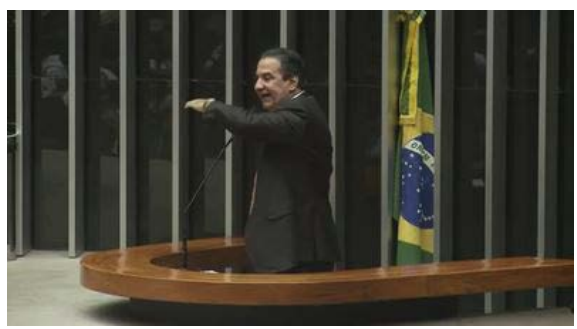

(2)

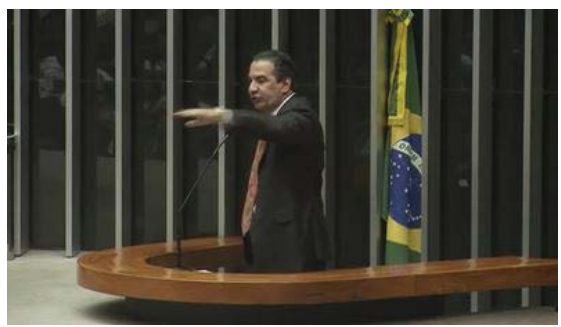

(3)

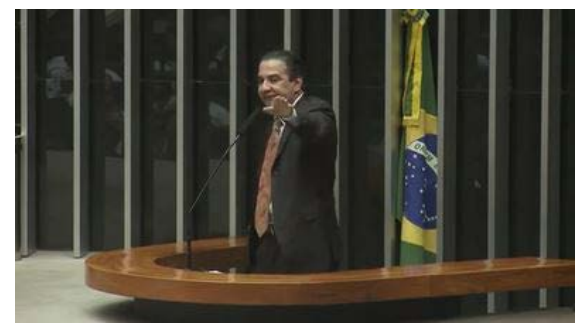

Source: TV Câmara's (House of Representatives TV) Youtube channel.

Horizontal left forearm, palm down, extended fingers, positioned to the right (1), to the center (2), and to the left side of the body

In the last selected scene, which occurs at the end of Malafaia'a speech, the utterance's metaphoricity is projected from the spatial source-domain. This utterance is highly conventional and can be interpreted as an assertive speech act, which is typically stated in a conclusive sequence of a parliamentary discourse. The speech is anchored in multimodal deictic resources, depicted by the horizontally extended arm movement made from right to left. Through this gesture, the pastor mimetically projects the image of a base or a foundation, metaphorically showing ("Here it is") to the interlocutor "the support for the history of the human race". In 
his concept, this support would be the nuclear family.

\subsection{Marco Feliciano's speech}

To analyze the multimodal metaphors of Feliciano's speech, we have selected two scenes. As the video has only $4 \mathrm{~min} 02 \mathrm{sec}$, we just selected scenes that could summarize the Representative's standpoint, as well as the metaphoric use made by him: the first scene occurred at $02 \mathrm{~min} 37 \mathrm{sec}$, and the second at $02 \mathrm{~min} 47 \mathrm{sec}$.

Sequence \#1

"O que as pessoas chamam de progressismo bate de frente, frontalmente $(1,2)$ com a família brasileira"./ "What people call progressivism clashes, frontally $(1,2)$ with the Brazilian family".

(1)

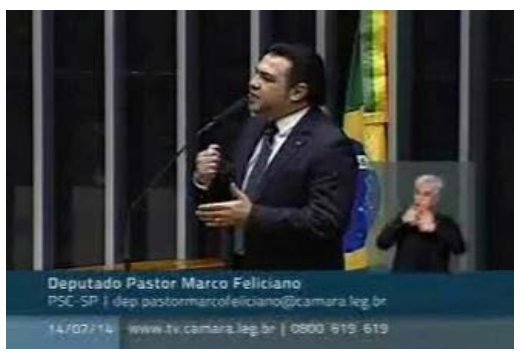

(2)

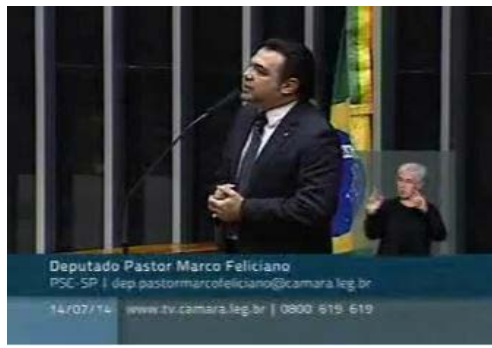

Source: TV Câmara's (House of Representatives TV) Youtube channel.

(1) Fist-closed right hand, oblique forearm, palm-oblique left hand, fingers extended, horizontal forearm (2) Right hand punching left hand, left fingers closing on the right hand

The first selected scene from Feleciano's speech is very illustrative of his speech conditions of production: the context is characterized by an intervention in the House of Representatives tribune, made by him as the Social-Christian Party (PSC) leader. His pronouncement addresses an interview made by Estadão, a Brazilian newspaper with widespread circulation, with Manoel Carlos, the screenwriter of "In Family" (Em Família), the soap opera aired at the time by the Brazilian TV channel, Globo. 
Assuming a polemic standpoint, the pastor states that "progressivism clashes, frontally with the Brazilian family". The metaphoricity degree is so highly conventionalized that the expression "bater de frente" (clash ) can be considered an idiom in Brazilian Portuguese. The gesture of punching the open left hand with the right, in this case, rhetorically strengthens the speech. This scene metaphorically describes the confrontation discursively constructed by the PSC leader, between what is generically called "progressivism" (all forms of family configurations that do not fit in the traditional concept of family) and the so-called "Brazilian family" (the traditional family configuration). The detailed discussion of this scene will be further addressed in the next section (Section 4).

\section{Sequence \#2}

"Nós vivemos num país onde mais de $80 \%$ da população prima (1) pelo pai e pela mãe e ainda pede bênção (2)"/ "We live in a country where more than $80 \%$ of the population fight (1) for the father and the mother, and still ask for their blessing (2)."

(1)

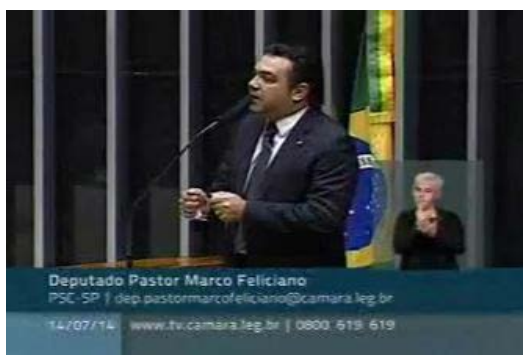

(2)

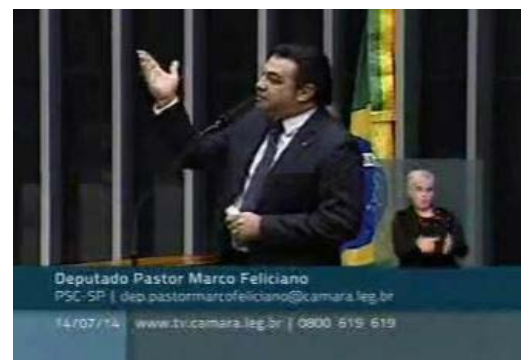

Source: TV Câmara's (House of Representatives TV) Youtube channel.

(1) Both fist-closed hands facing each other, horizontal forearms in front of the body

(2) Palm-up open hand, extended fingers, vertical forearm, ascending trajectory away from the body

In this second scene, Feliciano argues that the vast majority of the population "fight for and ask for the father's and the mother's blessing." At first glance, the utterance's highly conventionalized interpretation does not seem to be metaphoric, but when we take the gestures into consideration, it does. In the first utterance, the 
unfolded gesture, with hands positioned symmetrically and in parallel in front of the body, metaphorically depicts the strength of a person that holds and conducts an object, such as an animal's reins. Next, when he says “(...) and ask for their blessing", Feliciano extends his right arm in an ascendant trajectory and opens his hand, depicting a supplication (of a blessing) to the parents, or even, to God.

\section{DISCUSSION}

Considering the limitations of time and space to develop this paper, we decided to make a qualitative analysis from the scenes that best illustrated the metaphoric unfolding in both speeches, anchored in our Multimodal Semiotic Blending (MSB) model. Hence, we pointed out the most relevant semiotic and enunciative characteristics of the analyzed pronouncements. To do so, the general diagram presented in Section 1.1 was applied to one sample from each pastor: Malafaia and Feliciano.

On the one hand, it is clear that both speeches are very similar, considering the speakers' political-ideological standpoints about the "family" issue, as both Representatives are from the Evangelical Bench, and more specifically from the Social-Christian Party (PSC). Furthermore, both speeches were made in the House of Representatives tribune in the Brazilian National Congress.

On the other hand, these speeches can be distinguished by some specific circumstances: Malafaia's speech, as already mentioned, is proffered at the "Solemn Session in Honor of the Family Day". As a result, his speech presents typical features from the rhetoric epidictic genre. He starts his speech saying that "this is a very special day, because it's impossible for a human being to develop $\mathrm{him} /$ herself without a family", and develops his statement glorifying the so-called "nuclear family", based on "heteronormative relations" and on the "father's authority." Malafaia assumes an allegedly didactic posture, reverting to axioms from fields such as Psychology - and to an analogical reasoning to persuade his audience. In his own words, "God, as any institution, needs an organization (...) Thus, God creates an organization, in this institution called family, and puts the man as the authority (...)."

To analyze the MSB architecture, we will analyze the scene in which Malafaia states that "the human being is a sponge." 


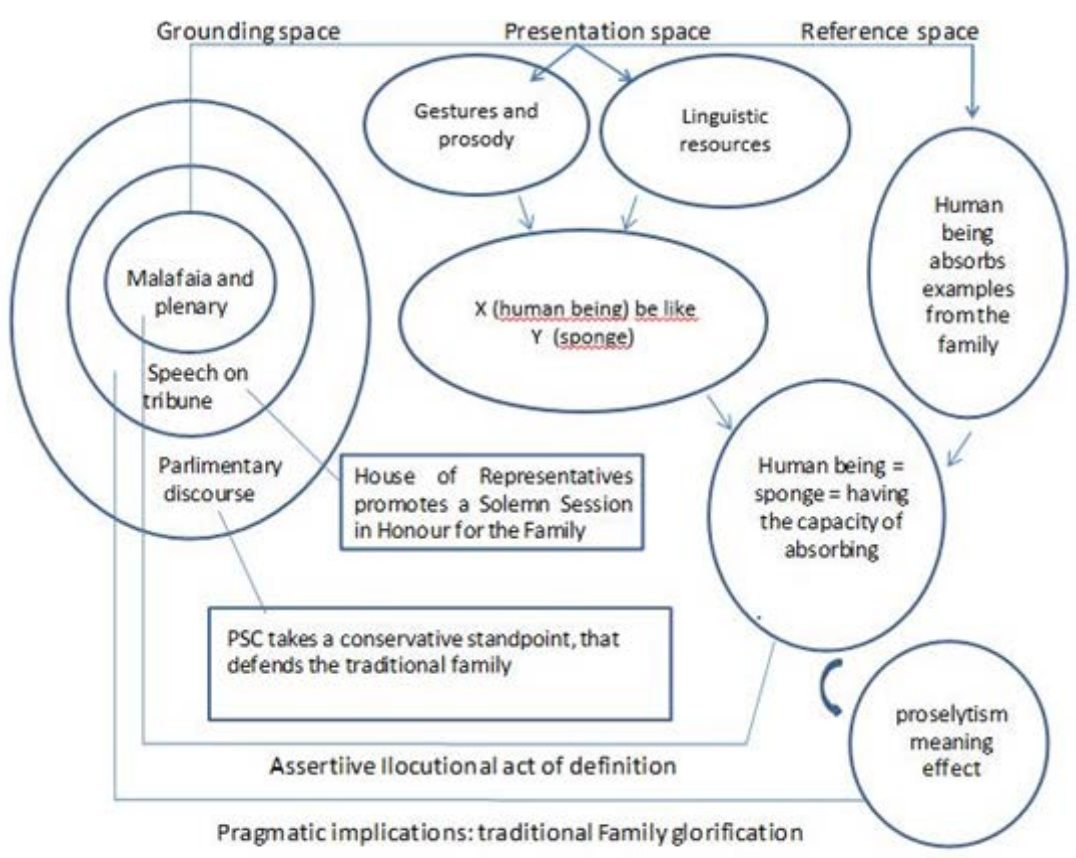

FIGURE 3

Source: Elaborated by the authors

Feliciano's speech, as already mentioned, is a plenary session made by him as the PSC leader. According to his own speech, his motivation to talk arose from an interview conducted by the newspaper "Estadão" with the screenwriter Manoel Carlos, the author of "In Family" (Em Família), the soap opera aired by Globo that presented a gay kiss between two women. The Representative states that "what brings me here this afternoon, Ms. President [addressing Benedita da Silva, the President of the Session], is a story that came out this afternoon in Estadão, precisely in section two, an interview conducted with the great Brazilian screenwriter Manoel Carlos (...)." Feliciano mentions a question made by the interviewer about the soap opera's low audience, and criticizes Manoel Carlos' answer that "Brazilian society is still misogynist." Assuming himself as a conservative person, the Representative pastor says that "Brazilian population can't stand seeing the traditional family being deconstructed on TV anymore." This utterance presents a relatively conventionalized degree of metaphoricity, related to the meanings of (de)construction and its cognates. 
Wewill take up the scene in which Feliciano states: "What peoplecall progressivism clashes, frontally with Brazilian family". This utterance's metaphoricity can be related to Talmy's (2000) force dynamics, in which "progressivism" is an antagonist in conflict with the "Brazilian family" agonist.

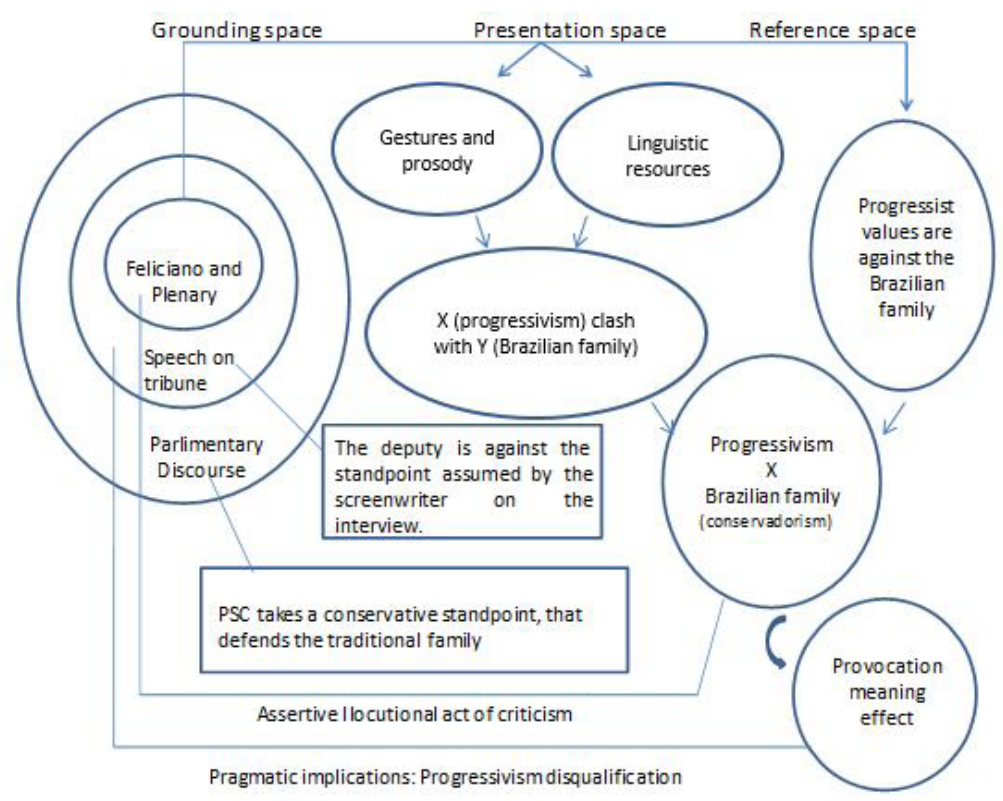

FIGURE 4

Source: Elaborated by the authors

\section{FINAL REMARKS}

The analysis of the multimodal metaphors used by the Representatives enabled us to discuss strategies (not only verbal) used by them to convey a determined system of values and, with this, persuade or not the constituencies. The performed analysis enabled us to validate the general hypothesis that our conceptual system is broader than our linguistic system. In other words, the analysis of the interrelation between the verbal and the gestural factors allows one to overcome the criticism of circularity made by the Conceptual Metaphor Theory (LAKOFF; JOHNSON, 1980), which tautologically claims that: "Verbal metaphoric expressions are evidence of conceptual metaphors (...). We know that because we see conceptual metaphors expressed in language." (CIENKI apud CIENKI, 2008, p. 16). 
Regarding the model (MSB), this new proposition allows for the analysis of material resources, such as gestures, in which the enunciation is systematically anchored (AUCHLIN, 2013), and that points out how, and not just what, the enunciation, as well as the represented shared meaning, is being constructed. In other words, the Presentation Space unfolding allows for the integration of the abstract conceptual representation, together with the sensorimotor experience of the enunciation's material characteristics. Consequently, it allows one to show, in detail, how each modality works, how they interact, and then, after having being integrated within the linguistic information, how they can be metaphorically presented.

\section{Análise multimodal de metáforas no discurso político- religioso: uma abordagem semiótico-cognitiva}

\section{Resumo}

Este artigo analisa a inter-relação entre gestos e fala na construção de metáforas multimodais no gênero "sessão legislativa". Baseado na Integração Semiótica Multimodal (ISM), uma adaptação do modelo de Brandt e Brandt (2005) (MIRANDA; MENDES, 2004; AVELAR, no prelo), foi feita uma análise ilustrativa das metáforas multimodais encontradas nas sessões, focalizando os recursos verbais e gestuais utilizados pelos participantes. Para tanto, foram selecionadas cinco cenas do discurso de dois autointitulados "deputados-pastores": Marco Feliciano e Silas Malafaia. Por fim, as metáforas e gestos utilizados por ambos os deputados foram comparados. A conclusão alcançada neste estudo demonstrou como o ISM pode ser relevante quando se analisa a iconicidade dos recursos materiais (sobretudo os gestos) utilizados pelos participantes.

Palavras-chave: Semiótica Cognitiva. Integração Semiótica Multimodal. Discurso político-religioso. Política brasileira. Sessões Legislativas. 


\section{References}

AUCHLIN, A. Prosodic Iconicity and Experiential Blending. In: HANCIL, S. (Ed.) Prosody and Iconicity. Amsterdam: John Benjamins, 2013. p. 1-31.

AVELAR, M. The emergence of multimodal metaphors in Brazilian politicalelectoral debates: a comparative analysis of the 2010 and 2014 second-round presidential debates. In: ZLATEV, J; KONDERAK, P; SONESSON, G. (Eds.). Establishing Cognitive Semiotics. Frankfurt am Main: Peter Lang, in print.

BRANDT, L.; BRANDT, P. Making sense of a Blend. Annual Review of Cognitive Linguistics, Amsterdam, v. 3, p. 216-249, 2005.

CIENKI, A. Why to study metaphor and gesture? IN: CIENKI, A.; MÜLLER, C. Metaphor and gesture. Amsterdam: John Benjamins, 2008, p. 3-26

KENDON, A. Gesture: visible action as utterance. Cambridge: Cambridge University Press, 2004.

LAKOFF, G.; JOHNSON, M. Metaphors we live by. Chicago, London: The University of Chicago Press, 2003. Original publicado em 1980.

MIRANDA, M.; MENDES, P. A emergência de metáforas multimodais: análise da metaforização e da compressão no debate político-eleitoral. Scripta, Belo Horizonte, v. 18, n.34, p. 237-256, 2014.

MÜLLER, C.; CIENKI, A. Words, gestures, and beyond: Forms of multimodal metaphor in the use of spoken language. In: FORCEVILLE, C.; URIOS-APARISI, E. (Org.) Multimodal metaphors. Berlin, New York: Mouton de Gruyter, 2009. p. 297-328.

TALMY, L. Toward a Cognitive Semantics. Volume I: Concept Structuring System. Cambridge, Mass: The MIT Press, 2000.

TURNER, M. Conceptual Integration. In: GEERAERTS, D.; CUYCKENS, H. (eds). The Oxford Handbook of Cognitive Linguistics. Oxford: Oxford University Press, 2007. p. 377-393.

Recebido em 14/06/2016.

Aceito em 15/08/2016. 